\title{
Sociodemographic differences in the occurrence of teenage pregnancies in Finland in 1987-1998: a follow up study
}

\author{
A Vikat, A Rimpelä, E Kosunen, M Rimpelä
}

See end of article for authors' affiliations

Correspondence to: Dr A Vikat, Max Planck Institute for Demographic Research, Doberaner Strasse 114, D-18057 Rostock, Germany; vikat@demogr.mpg.de

Accepted for publication 28 January 2002
Study objective: To analyse sociodemographic differences in the occurrence of pregnancies to 14 to 19 year olds and changes in these differences from 1987 to 1998.

Design: Follow up of adolescent survey respondents using registers.

Setting and subjects: The dataset includes information on all registered pregnancies (abortions, births, and miscarriages, $n=2743$ ) of the female respondents ( $n=28$ 914) to the Adolescent Health and Lifestyle Survey (AHLS) from 1987 to 1998. In the AHLS, self administered questionnaires were mailed every second year to independent samples of 12, 14, 16, and 18 year olds representative for Finland. Main outcome measure: Relative risk (hazard) of becoming pregnant at teenage.

Main results: Girls from lower socioeconomic background had a higher pregnancy risk. Girls who did not live with both parents at the baseline survey had higher pregnancy risk than those who did, and girls who lived in a stepfamily had a higher risk than those who lived in a one parent family. Swedish speaking girls had a lower pregnancy risk than the Finnish speaking girls. There was no systematic change from 1987 to 1998 in most sociodemographic differentials in the teenage pregnancy risk, however, there was some increase in the differences by family structure. Changes in the sociodemographic structure did not explain the levelling off of the downward trend in teenage pregnancy risk, nor did the regional socioeconomic differences explain regional differentials in teenage pregnancy risk.

Conclusion: Although the reduction of socioeconomic and regional differences has been a general objective in Finnish social and health policies, the relative differences in teenage pregnancies have not decreased.
$\mathrm{F}$ inland has a successful track record of reducing unintended pregnancies. ${ }^{1}$ The abortion rate among all women of reproductive age halved from the first half of the 1970s to the mid-1990s ${ }^{2}$ and teenage abortion and pregnancy rates decreased even more. ${ }^{3}$ However, the favourable development stopped in the mid-1990s. From 1994 to 1997 the teenage pregnancy rate remained at the same level and the abortion rate slightly increased. The current levels of the teenage abortion rate $\left(13.5\right.$ per thousand in $\left.1999{ }^{4}\right)$ and fertility rate $(9.6$ per thousand in $1999^{5}$ ) in Finland are relatively low among the countries with reliable data. ${ }^{67}$

It is probable that a large proportion of teenage pregnancies in western countries are unplanned, though there is not much research evidence on that. One available estimate is $78 \%$ and pertains to the United States. ${ }^{8}$ In a Danish hospital study of pregnant women before 20th week of gestation, 52\% of all pregnancies among women age under 24 years $(n=761)$ were unplanned, whether accepted or terminated. ${ }^{9}$ In women aged under 20, the respective figure was 86\% (Vibeke Rasch, unpublished data). Although there are no direct estimates of this proportion in Finland, we can assume that the situation is very much the same. In the European context, the mean age of Finnish women at first birth, 27.4 years, is high, and the contribution of women below age 20 to total period fertility, $2.8 \%$, is low. ${ }^{7}$ In such a context the occurrence of adolescent pregnancies reflects adolescent sexual activity and success in preventive activities. Activities aimed at the reduction of adolescent pregnancies would thus contribute to the reduction of abortions and the reduction of unplanned births.

There are studies from other countries that have analysed the incidence of teenage pregnancies (or abortions or births) by sociodemographic background, ${ }^{10-17}$ most of them using data from the United States. Many studies have focused on area level associations of socioeconomic status and teenage pregnancy risk ${ }^{18}$ or birth risk, ${ }^{19} 20$ and there are a number of studies that analyse the pregnancy risk of teenage mothers by socioeconomic and family background. ${ }^{21}{ }^{22}$ Most of these studies, which use different methodologies, show that girls from a lower socioeconomic background (measured either on individual or area level) or from incomplete or stepfamilies have higher abortion, fertility, or pregnancy rates at adolescence than their counterparts with more favourable background characteristics. However, other examples also exist. In Switzerland, the father's level of education did not differentiate adolescents who had experienced pregnancy and those who had not. ${ }^{12}$ In the United States, Moore et al ${ }^{15}$ found no independent effect of family income after controlling for a number of other variables. Most of the evidence on socioeconomic differences in teenage pregnancy rates pertains to the United States and cannot be directly generalised to Finland or other European countries, because of the differences in the social structures and healthcare systems between these societies.

Finland is a Nordic welfare society that is sparsely populated and has a relatively large geographical area. The northern part of the country is even more sparsely populated, while the southern part is more urbanised and more affluent. Earlier Finnish studies on the regional variation in adolescent health behaviours have found that the regional differences were, to some extent, explained by the socioeconomic structures of the regions. ${ }^{23}{ }^{24}$ Finland has a Swedish speaking population that makes up $6 \%$ of the total population and is concentrated in the western and south western coast and the islands as well as in the capital Helsinki and in some locations 
in the surrounding Uusimaa region. Earlier studies have revealed that they have higher life expectancy and they remain active in working life longer than their Finnish speaking compatriots, the differences being astonishingly large for a highly monocultural and egalitarian society like Finland. ${ }^{25-27}$

There is an effective and comprehensive registration system of abortions and births in Finland. A recent analysis of these data showed that the levelling off of the trend in teenage pregnancy rates in the mid-1990s started first among older teenagers, and spread gradually to the younger girls. ${ }^{28}$ Regional variation in the rates remained the same from 1987 to 1999 , with the highest levels observed in the northernmost region of Lapland and in the capital Helsinki. ${ }^{28}$ However, there is little direct information on the association of socioeconomic and family background factors with teenage pregnancies and abortions, because the registers do not contain that background information and it is also difficult to obtain data on the population at risk by the sociodemographic background variables. Retrospective surveys could be an alternative way to study this area, however, it has been found that they often fail to provide reliable information on abortions. ${ }^{29}{ }^{30}$ In this study, we overcome many of these measurement difficulties by using a dataset that contains linked information from different sources.

The purpose of the study is

- to analyse sociodemographic differences in the occurrence of pregnancies of 14 to 19 year olds

- to determine whether any sociodemographic differences have changed over time from 1987 to 1998

- to assess whether changes in teenage pregnancy rates over time can be explained by changes in the sociodemographic structure of the teenage population

- to assess whether any regional variations in the teenage pregnancy rate could be accounted for by the socioeconomic differences between the regions.

\section{METHODS}

\section{Data sources}

Our dataset is formed by an individual level linkage of data from the Adolescent Health and Lifestyle Survey (AHLS), and the registers on reproduction (Register of Induced Abortion and Sterilisation, Medical Birth Register, and Hospital Care Register) maintained at the National Research and Development Centre for Welfare and Health (STAKES). The linked dataset includes information from 1987 to 1998 on all registered pregnancies (abortions, births, and miscarriages treated in a hospital) of the girls who were in the AHLS samples in 1987, 1989, 1991, 1993, 1995, and 1997, including the non-respondents. The data linkage was made by Statistics Finland and the identity of the study subjects was not available to us at any stage. The research plan and the data linkage procedure were approved by the ethics committee of the Pirkanmaa Hospital District, and by the Office of the Data Protection Ombudsman.

AHLS is a nationwide monitoring system of adolescent health and health behaviours with samples representing the $12,14,16$, and 18 year olds in the entire country (excluding the archipelago province of Åland). The samples were independent across survey years, and each individual was included only in one survey. The samples were obtained from the Population Register Centre and were based on selected dates of birth, so that all Finns born on given sample days were included. The mean ages of respondents were 12.6, 14.6, 16.6, and 18.6 years. Self administered questionnaires were mailed in February every second year with two re-inquiries to non-respondents. The timing of the study, sampling and data collection methods were similar throughout the study period. In 1987, 1991, and 1993 adolescents aged 14, 16, and 18 from
Table 1 Number of respondents and response rate by age, Adolescent Health and Lifestyle Survey 1987-1997

\begin{tabular}{rrrrrrrr}
\hline $\begin{array}{l}\text { Age at } \\
\text { survey }\end{array}$ & 1987 & 1989 & 1991 & 1993 & 1995 & 1997 & Total \\
\hline \multicolumn{2}{l}{$\begin{array}{c}\text { Number } \\
\text { of respondents }\end{array}$} & & & & & \\
12 & 363 & 430 & 395 & 436 & 423 & $*$ & 2047 \\
14 & 1856 & 431 & 2058 & 2008 & 1301 & 1346 & 9000 \\
16 & 1968 & 345 & 1912 & 2095 & 1469 & 1379 & 9168 \\
18 & 2201 & 354 & 1685 & 1929 & 1116 & 1414 & 8699 \\
Total & 6388 & 1560 & 6050 & 6468 & 4309 & 4139 & 28914 \\
& & & & & & & \\
Response rate (\%) & & & & & & \\
12 & 83 & 82 & 81 & 84 & 85 & $*$ & 84 \\
14 & 90 & 90 & 87 & 88 & 85 & 84 & 87 \\
16 & 89 & 82 & 87 & 87 & 88 & 87 & 87 \\
18 & 86 & 80 & 82 & 84 & 86 & 83 & 84 \\
Total & 88 & 84 & 85 & 86 & 86 & 85 & 86 \\
\hline
\end{tabular}

*Data on these respondents were not used in this study, because they did not reach age 14 by the end of the follow up period.

smaller provinces were over-sampled in order to obtain representative samples for each province. In the analyses we used data on all the girls who responded to the 1987 through to 1997 rounds of the survey (table 1). As we had information on the pregnancies of the entire samples, it was possible to calculate a pregnancy rate for those girls who did not return a filled questionnaire. This was $71 \%$ higher than that of the respondents.

According to an evaluation study, the Finnish Abortion Register includes $99 \%$ of abortions performed in the country. ${ }^{2}$ The Birth Register is consistency checked with the Population Register and covers virtually all births in Finland (for quality assessments, see references ${ }^{31-33}$ ). Information on miscarriages was retrieved from the Hospital Care Register and includes only those cases that involved inpatient treatment. According to a Finnish survey, $74 \%$ of women who have a miscarriage are treated as inpatients. ${ }^{34}$

\section{Study variables}

The start of any pregnancy measured with the precision of a month is the event under study, and we analyse the intensity (hazard) of the occurrence of this event as the dependent variable. The month of the start of pregnancy was obtained from the register data, using information on the duration of pregnancy at the registered event (abortion or birth). In the case of miscarriage the duration of pregnancy was not available and was assumed to be two months.

Two explanatory variables, current age and calendar year, are time varying covariates with changing values in the course of the follow up. The other explanatory variables are obtained either from the sample data from the Population Register (place of residence and mother tongue) or from the response to the AHLS, and refer to the time of the survey.

Adolescence is a transient stage where it is not self evident how to measure socioeconomic status, because the adolescent girl's own occupation recorded at that age does not reflect her true status. For an adequate measure, information on the status of the parents is needed. We used two measures that represent different dimensions of socioeconomic status: one was the status classified on the basis of occupation and the other was the level of education. Both of them referred to the father if he was present in the family, and to the guardian (most often the mother) if the father was not present. In the following, we present our study variables with the percentage of respondents in each category presented in the parentheses.

- Father's or other guardian's level of education has three categories: high, which is estimated to represent 12 years or more in education ( $17 \%$ of all the respondents), middle, 


\begin{tabular}{|c|c|c|c|c|c|c|c|}
\hline \multirow[b]{2}{*}{ Year } & \multicolumn{6}{|l|}{ Age } & \multirow[b]{2}{*}{ Total } \\
\hline & 14 & 15 & 16 & 17 & 18 & 19 & \\
\hline \multicolumn{8}{|c|}{ Number of pregnancies } \\
\hline 1987 & 3 & 3 & 18 & 27 & 52 & 74 & 177 \\
\hline 1988 & 0 & 9 & 15 & 34 & 39 & 67 & 164 \\
\hline 1989 & 2 & 5 & 21 & 34 & 58 & 82 & 202 \\
\hline 1990 & 1 & 9 & 4 & 39 & 44 & 69 & 166 \\
\hline 1991 & 3 & 12 & 21 & 35 & 101 & 120 & 292 \\
\hline 1992 & 1 & 10 & 10 & 38 & 40 & 103 & 202 \\
\hline 1993 & 3 & 5 & 44 & 31 & 75 & 103 & 261 \\
\hline 1994 & 0 & 10 & 17 & 62 & 73 & 136 & 298 \\
\hline 1995 & 3 & 7 & 21 & 42 & 124 & 155 & 352 \\
\hline 1996 & 0 & 6 & 12 & 34 & 74 & 152 & 278 \\
\hline 1997/1998* & 1 & 7 & 26 & 40 & 125 & 152 & 351 \\
\hline Total & 17 & 83 & 209 & 416 & 805 & 1213 & 2743 \\
\hline \multicolumn{8}{|c|}{ Number of person years $\dagger$} \\
\hline 1987 & 800 & 901 & 846 & 945 & 931 & 1031 & 5454 \\
\hline 1988 & 182 & 953 & 897 & 1003 & 940 & 1095 & 5071 \\
\hline 1989 & 361 & 396 & 1086 & 1067 & 1129 & 1105 & 5143 \\
\hline 1990 & 215 & 396 & 395 & 1109 & 1062 & 1146 & 4323 \\
\hline 1991 & 1121 & 1191 & 1230 & 1298 & 1786 & 1863 & 8489 \\
\hline 1992 & 198 & 1290 & 1191 & 1381 & 1290 & 1905 & 7254 \\
\hline 1993 & 1066 & 1168 & 2197 & 2183 & 2214 & 2175 & 11003 \\
\hline 1994 & 218 & 1232 & 1165 & 2365 & 2173 & 2349 & 9502 \\
\hline 1995 & 795 & 832 & 1882 & 1850 & 2819 & 2671 & 10848 \\
\hline 1996 & 212 & 903 & 830 & 1993 & 1842 & 2873 & 8652 \\
\hline 1997/1998* & 772 & 1178 & 1497 & 2004 & 2581 & 3338 & 11370 \\
\hline Total & 5938 & 10441 & 13216 & 17198 & 18767 & 21549 & 87108 \\
\hline
\end{tabular}

representing from 9 to 11 years in education (15\%), and low, at most 8 years in education $(68 \%)$.

- Father's or other guardian's occupation is classified by the status classification of Statistics Finland: upper white collar employee $(21 \%)$, lower white collar employee $(29 \%)$, farmer $(9 \%)$, and blue collar employee $(42 \%)$.

- Family structure: the adolescent living with both parents (76\%), with own parent and stepparent $(8 \%)$, with one parent $(13 \%)$, with her own partner $(3 \%)$, other, that is, not living together with either of own parents nor with a partner $(1 \%)$. In the 1987 survey the distinction could only be made between the category living with both parents and all the others

- Region: 11 provinces according to the official division of provinces until 1997.

- The urbanisation level of the place of residence is defined by population density: capital city area (the capital Helsinki and the adjoining towns, $11 \%$ ), larger towns (population over $50,000,16 \%)$, smaller towns and other settlements (including densely populated areas in rural municipalities, $59 \%$ ), and sparsely populated rural areas (isolated homesteads in rural municipalities, $14 \%$ ).

- Mother tongue: Finnish (97\%), Swedish (3\%).

\section{Statistical analysis}

We used intensity (hazard) regression to estimate models of pregnancy risks of teenagers. Regression models were fitted using the GLIM software package. ${ }^{35}$ The word pregnancy risk is used in this article to connote the intensity of the occurrence of pregnancies. The time reference of the pregnancy is its starting month. The follow up time starts from the month of response to the AHLS or at the 14th birthday for those who answered the questionnaire at age 12, and ends either with the respondent's 20th birthday or at the end of the observation period (28 February 1998). Our dataset includes data on events that are pregnancy outcomes, whereas we analyse the event of the start of pregnancy. Pregnancies that start after February 1998 may have ended in a birth only in 1999 and are thus not included in the data. Therefore we censor all the observations at the end of February 1998. The time during which a respondent was pregnant is excluded from the follow up time, but respondents re-entered follow up after the end of the pregnancy. The numbers of observed pregnancies and person years of exposure by age and calendar year are presented in table 2. All time related data were analysed at the precision of month.

In the first step of the analysis we fitted separate hazard models for each explanatory variable, controlling only for age. The purpose of these models is to describe the differences in the pregnancy risk by each variable, and they also serve as a baseline contrast to the model with all significant variables. They are labelled as baseline models. As a starting point of the second step we fitted a model that included all the variables that were significantly associated with pregnancy risk in the first step and were measured in each round of the survey. A backward stepwise procedure was applied to this model to find the most parsimonious model based on the variables that were measured throughout the study period. This is labelled as the multivariate model. The comparison of the estimates of this model with the ones obtained from the baseline models answers to the questions whether some of the change over time or some of the regional variation could be explained by other sociodemographic variables. In the third step, we ran the multivariate model using the subsample when the detailed family composition was measured (this was not measured only in the 1987 survey). This model is denoted as the family structure model.

In the fourth step, we checked all the possible first level interactions between the explanatory variables to study the changing effects over time (interactions of each variable with calendar year) and to make sure that any subgroups that would require separate analysis were not omitted. We used the 
continuous specification of the calendar year to test for a significant linear change over time in the sociodemographic differences, and the categorical specification (also by using groups of adjacent years as categories) to examine the pattern of relative risks that might display other than a linear change. The interaction estimates were obtained both as adjusted only for age and as adjusted for all the variables in the multivariate model. Our statements about significance are based on the likelihood ratio test at the five per cent level. In addition, we also present results from some other models to show how the relative risks by level of urbanisation changed from one model to another.

\section{RESULTS}

\section{Sociodemographic differences}

Socioeconomic status

Differences in pregnancy risk by father's or guardian's occupation and level of education were large (baseline models in table 3). A girl from a blue collar family had 2.5 times the risk of becoming pregnant at teenage compared with a girl from an upper white collar family, and there were significant differences between each of the four occupational statuses. Daughters of farmers had a pregnancy risk that was between that of lower and upper white collar families. Girls whose fathers had less than nine years of education had 2.2 times the pregnancy risk of those whose fathers had 12 or more years of education.

In the multivariate model, the relative pregnancy risks by father's occupation and level of education were smaller than in the baseline models (table 3 ). This is related to the known correlation between these two variables. When one of them was dropped from the multivariate model, the relative risks of the other were close to the corresponding relative risks in the baseline model. They became smaller only when they were both in a model simultaneously. As father's occupation and level of education retained their significant independent effects they were both kept in the multivariate model to have the best available control for socioeconomic background in the relative risks of the other variables.

\section{Family structure}

Girls whose family composition in the survey was other than living with both parents had 2.3 times the pregnancy risk of those who lived together with their parents (table 3 ). When looking at different family types in more detail, four different levels could be distinguished. Those girls who already lived together with their partner and those who belonged to the category other had the highest pregnancy risk (table 4). Girls who had a step-parent (both those living with her mother and stepfather and those with father and stepmother) had the next highest pregnancy risk, followed by those living in a one parent family. Girls who lived with both parents had by far the lowest pregnancy risk.

There was very little change in the relative pregnancy risks by family structure from the baseline model to the multivariate model that controlled for all the other significant variables. In particular, it is worth noting that the pregnancy risk of girls who lived with an own parent and a step-parent remained $29 \%$ higher than that of girls in one parent families (table 4; the $\mathrm{p}$ value for this particular contrast was $<0.01$ ). We also checked for the effect of whether the adolescent's own parent in these families was the mother or the father, and found none. Girls living with only the father had levels of pregnancy risk remarkably close to those living with only the mother, and girls living with father and stepmother, and mother and stepfather also had an equal risk (numerical results available on request).

Given the known age dependency of family structure, particularly the increase with age of the proportion of those not living with their parents and living with a partner, we also checked for the influence of controlling for age at the survey on the relative risks and tested the interaction of family structure with age at the survey. The interaction was not significant and did not show any pattern.

\section{Mother tongue}

There was a remarkably large difference between the two language groups in Finland: the Swedish speaking girls had a $39 \%$ lower pregnancy risk than their Finnish speaking counterparts (table 3). The difference by mother tongue became smaller especially when the father's occupation and level of education were controlled for, reflecting the fact that Swedish speaking girls come, on average, from higher socioeconomic groups. In our data, 33\% of Swedish speaking and $20 \%$ of Finnish speaking girls came from upper white collar families. When controlled for all the variables that were present in the multivariate model, the Swedish speaking girls still had a 32\% lower pregnancy risk than the Finnish speaking girls.

\section{Change over time}

The relative pregnancy risks by calendar year showed that there was a decline up to the mid-1990s and a levelling off after that (table 3), which is consistent with the teenage pregnancy trend observed in the total population. There was only very little difference between the relative risk by calendar year estimated from the baseline model and those from the multivariate model, which indicates that change in the sociodemographic structure of the teenage population does not explain the time trend.

We studied whether there was any change in the observed sociodemographic differences over time, by checking interactions of each variable with calendar year (we used both the categorical and continuous specifications of the calendar year and tried several categorical specification by grouping adjacent years). There was some indication that the differences between girls from intact and other families increased over time. In 1987-1989 the relative risk (controlled only for age) of girls who did not live with both parents was 2.01 times that of girls with both parents; this relative risk was 2.04 in 1990-1991, 2.56 in 1992-1994, and 2.37 in 1995-1998. The interaction with the family structure and year as a continuous variable was significant $(p=0.04)$ when added to the model that included the main effects of these variables and age. Some variation could be observed also in the relative risks of other variables over the study period, but there was no systematic pattern and the $\mathrm{p}$ values for their interaction with the calendar year remained above 0.25 at all the different specifications for the calendar year. We conclude that there was no significant change over time in the effects of the other study variables except family structure.

\section{Regional differences}

When studied by region, the pregnancy risk was the highest in the north of the country and in the capital city area, and lowest in some western coastal regions and in the south east. There was no sign of an overall reduction or increase of regional differences, however, a small change in the relative risks in two provinces could be noted from the baseline model to the multivariate model. Teenage pregnancy risk in the provinces of Uusimaa (in the south of the country, includes the capital Helsinki and its surroundings) and Vaasa (at the western coast) was a little higher in the multivariate model. In the case of Uusimaa this was related to the concentration of people with a higher education and at a higher occupational status around the capital. The percentage of girls from the families of upper white collar employees was 35\% in Uusimaa and $18 \%$ in the rest of the country and the corresponding percentages of those whose father or guardian had at least 12 years of education were $32 \%$ and $14 \%$. In the case of Vaasa this 
Table 3 Relative pregnancy risks estimated from hazard regression models. Respondents to the 1987-1997 surveys

\begin{tabular}{|c|c|c|c|c|}
\hline \multirow[b]{2}{*}{ Variable Category } & \multicolumn{2}{|c|}{ Baseline models: Age + Variable } & \multicolumn{2}{|c|}{ Multivariate model* } \\
\hline & $\begin{array}{l}\text { Relative } \\
\text { risk }\end{array}$ & $\begin{array}{l}95 \% \text { confidence } \\
\text { intervals }\end{array}$ & $\begin{array}{l}\text { Relative } \\
\text { risk }\end{array}$ & $\begin{array}{l}95 \% \text { confidence } \\
\text { intervals }\end{array}$ \\
\hline \multicolumn{5}{|l|}{ Age $†$} \\
\hline 14 & 0.05 & 0.03 to 0.08 & 0.05 & 0.03 to 0.09 \\
\hline 15 & 0.14 & 0.11 to 0.18 & 0.15 & 0.12 to 0.19 \\
\hline 16 & 0.28 & 0.24 to 0.33 & 0.28 & 0.24 to 0.33 \\
\hline 17 & 0.43 & 0.38 to 0.48 & 0.44 & 0.39 to 0.49 \\
\hline 18 & 0.76 & 0.70 to 0.83 & 0.75 & 0.68 to 0.82 \\
\hline 19 & 1 (ref) & & 1 (ref) & \\
\hline \multicolumn{5}{|l|}{ Year } \\
\hline 1987 & 1 (ref) & & 1 (ref) & \\
\hline 1988 & 0.90 & 0.72 to 1.11 & 0.93 & 0.74 to 1.16 \\
\hline 1989 & 1.04 & 0.85 to 1.27 & 1.08 & 0.88 to 1.34 \\
\hline 1990 & 0.92 & 0.74 to 1.13 & 0.98 & 0.78 to 1.22 \\
\hline 1991 & 0.97 & 0.80 to 1.17 & 0.98 & 0.80 to 1.19 \\
\hline 1992 & 0.73 & 0.59 to 0.89 & 0.73 & 0.59 to 0.90 \\
\hline 1993 & 0.67 & 0.55 to 0.81 & 0.69 & 0.56 to 0.84 \\
\hline 1994 & 0.78 & 0.64 to 0.93 & 0.82 & 0.67 to 1.00 \\
\hline 1995 & 0.81 & 0.67 to 0.96 & 0.85 & 0.71 to 1.03 \\
\hline 1996 & 0.73 & 0.60 to 0.88 & 0.77 & 0.63 to 0.94 \\
\hline $1997 / 1998$ & 0.74 & 0.62 to 0.89 & 0.79 & 0.66 to 0.96 \\
\hline \multicolumn{5}{|l|}{ Father's or guardian's occupation } \\
\hline Upper white collar & 1 (ref) & & 1 (ref) & \\
\hline Lower white collar & 1.90 & 1.66 to 2.18 & 1.27 & 1.08 to 1.50 \\
\hline Farmer & 1.53 & 1.27 to 1.84 & 1.12 & 0.90 to 1.40 \\
\hline Blue collar & 2.46 & 2.16 to 2.79 & 1.61 & 1.35 to 1.90 \\
\hline \multicolumn{5}{|c|}{ Father's or guardian's level of education } \\
\hline 12 or more years & 1 (ref) & & 1 (ref) & \\
\hline $9-11$ years & 1.39 & 1.16 to 1.65 & 1.15 & 0.94 to 1.40 \\
\hline Not more than 8 years & 2.21 & 1.92 to 2.54 & 1.63 & 1.36 to 1.95 \\
\hline \multicolumn{5}{|l|}{ Living with both parents } \\
\hline Yes & 1 (ref) & & 1 (ref) & \\
\hline No & 2.29 & 2.12 to 2.47 & 2.24 & 2.06 to 2.44 \\
\hline \multicolumn{5}{|l|}{ Mother tongue } \\
\hline Finnish & 1 (ref) & & 1 (ref) & \\
\hline Swedish & 0.61 & 0.46 to 0.80 & 0.68 & 0.50 to 0.93 \\
\hline \multicolumn{5}{|l|}{ Urbanisation } \\
\hline Sparsely populated rural areas & 1 (ref) & & & \\
\hline Towns and other settlements & 1.19 & 1.06 to 1.33 & & \\
\hline Larger towns & 1.22 & 1.06 to 1.41 & & ns \\
\hline Capital city area & 1.15 & 0.98 to 1.35 & & \\
\hline \multicolumn{5}{|l|}{ Region (province) } \\
\hline \multicolumn{5}{|l|}{ Central and western: } \\
\hline Central Finland & 1 (ref) & & 1 (ref) & \\
\hline Vaasa & 0.96 & 0.79 to 1.17 & 1.05 & 0.86 to 1.28 \\
\hline \multicolumn{5}{|l|}{ South: } \\
\hline Uusimaa & 0.96 & 0.81 to 1.14 & 1.05 & 0.88 to 1.25 \\
\hline Kymi & 0.79 & 0.64 to 0.97 & 0.75 & 0.61 to 0.93 \\
\hline \multicolumn{5}{|l|}{ Southwest: } \\
\hline Turku & 1.02 & 0.85 to 1.23 & 1.02 & 0.85 to 1.22 \\
\hline Häme & 1.00 & 0.83 to 1.21 & 1.00 & 0.83 to 1.20 \\
\hline \multicolumn{5}{|l|}{ East: } \\
\hline Mikkeli & 0.89 & 0.72 to 1.10 & 0.87 & 0.71 to 1.08 \\
\hline North Karelia & 1.11 & 0.90 to 1.37 & 1.09 & 0.89 to 1.35 \\
\hline Kuopio & 1.11 & 0.92 to 1.35 & 1.09 & 0.90 to 1.32 \\
\hline \multicolumn{5}{|l|}{ North: } \\
\hline Oulu & 1.17 & 0.97 to 1.41 & 1.20 & 1.00 to 1.44 \\
\hline Lapland & 1.32 & 1.09 to 1.60 & 1.29 & 1.07 to 1.56 \\
\hline $\begin{array}{l}\text { * Multivariate model }=\text { Age }+ \text { Yea } \\
\text { †The relative risks presented for a } \\
\text { contains only age. Those relative } \\
\text { level are in bold type. }\end{array}$ & $\begin{array}{l}\text { Dccupatio } \\
\text { the base } \\
\text { that differ }\end{array}$ & $\begin{array}{l}\text { Education + Both par } \\
\text { model (first column) a } \\
\text { nificantly from the refe }\end{array}$ & $\begin{array}{l}\text { Mother } \\
\text { timated } f \\
\text { e categor }\end{array}$ & $\begin{array}{l}\text { gue }+ \text { Province. } \\
\text { a model that } \\
95 \% \text { confidence }\end{array}$ \\
\hline
\end{tabular}

was related to the fact that this province had the highest proportion of adolescents living in intact families (82\% compared with $76 \%$ in the rest of the country) and the highest share of Swedish speaking adolescents ( $13 \% v 2 \%)$, both these groups having a relatively low teenage pregnancy risk.

Pregnancy risk increased by level of urbanisation, though the differences between the types of urban areas were not significant in the baseline model (table 3). Girls living in sparsely populated rural areas had the lowest pregnancy risk. When all the other variables were in the model, the level of urbanisation was not significant (multivariate model in table 3). However, the relative risks by level of urbanisation and the significance of the variable varied considerably across different models (table 5). Controlling for socioeconomic status changed both the size and the pattern of the differences by level of urbanisation. The capital city area became distinguished as the area with the highest pregnancy risk. However, the size of the differences was again reduced after controlling additionally for other variables, of which the inclusion of living with both parents was critically important. 
Table 4 Relative pregnancy risks by family structure, estimated from hazard regression models. Respondents to the 1989-1997 surveys

\begin{tabular}{|c|c|c|c|c|}
\hline \multirow[b]{2}{*}{ Family structure } & \multicolumn{2}{|c|}{$\begin{array}{l}\text { Baseline model }= \\
\text { Age + Family structure }\end{array}$} & \multicolumn{2}{|c|}{$\begin{array}{l}\text { Multivariate family } \\
\text { structure model* }\end{array}$} \\
\hline & $\begin{array}{l}\text { Relative } \\
\text { risk }\end{array}$ & $\begin{array}{l}95 \% \text { confidence } \\
\text { intervals }\end{array}$ & $\begin{array}{l}\text { Relative } \\
\text { risk }\end{array}$ & $\begin{array}{l}95 \% \text { confidence } \\
\text { intervals }\end{array}$ \\
\hline Both parents & 1 (ref) & & 1 (ref) & \\
\hline Parent and step-parent & 2.59 & 2.27 to 2.96 & 2.50 & 2.16 to 2.89 \\
\hline One parent & 1.96 & 1.74 to 2.22 & 1.94 & 1.69 to 2.22 \\
\hline Living with her own partner & 5.13 & 4.29 to 6.15 & 4.29 & 3.49 to 5.27 \\
\hline $\begin{array}{l}\text { Other (not living together with either of } \\
\text { own parents nor with a partner) }\end{array}$ & 4.34 & 3.12 to 6.02 & 4.65 & 3.28 to 6.59 \\
\hline
\end{tabular}

*Family structure model $=$ Age + Year + Occupation + Education + Family structure + Mother tongue + Province. Those relative risks that differ significantly from the reference category at $95 \%$ confidence level are in bold type.

\begin{tabular}{|c|c|c|c|c|c|c|}
\hline & \multicolumn{6}{|c|}{ Variables in the model in addition to the level of urbanisation } \\
\hline & Age & Age + Year & $\begin{array}{l}\text { Age }+ \text { Year+ } \\
\text { Occupation+ } \\
\text { Education }\end{array}$ & $\begin{array}{l}\text { Age +Year+ } \\
\text { Both Parents }\end{array}$ & $\begin{array}{l}\text { Age+Year+ } \\
\text { Occupation+ } \\
\text { Education+ Both } \\
\text { Parents }\end{array}$ & $\begin{array}{l}\text { Age +Year+ } \\
\text { Occupation+ } \\
\text { Education+ Both } \\
\text { Parents + Province }\end{array}$ \\
\hline Sparsely populated rural areas & 1 (ref) & 1 (ref) & 1 (ref) & 1 (ref) & 1 (ref) & 1 (ref) \\
\hline Towns and other settlements & $\begin{array}{l}1.19 \\
1.06 \text { to } 1.33\end{array}$ & $\begin{array}{l}1.19 \\
1.06 \text { to } 1.33\end{array}$ & $\begin{array}{l}1.16 \\
1.02 \text { to } 1.33\end{array}$ & $\begin{array}{l}1.08 \\
0.96 \text { to } 1.21\end{array}$ & $\begin{array}{l}1.09 \\
0.96 \text { to } 1.25\end{array}$ & $\begin{array}{l}1.10 \\
0.96 \text { to } 1.25\end{array}$ \\
\hline Larger towns & $\begin{array}{l}1.22 \\
1.06 \text { to } 1.41\end{array}$ & $\begin{array}{l}1.23 \\
1.07 \text { to } 1.41\end{array}$ & $\begin{array}{l}1.28 \\
1.09 \text { to } 1.50\end{array}$ & $\begin{array}{l}1.06 \\
0.92 \text { to } 1.22\end{array}$ & $\begin{array}{l}1.15 \\
0.98 \text { to } 1.35\end{array}$ & $\begin{array}{l}1.18 \\
1.00 \text { to } 1.38\end{array}$ \\
\hline Capital city area & $\begin{array}{l}1.15 \\
0.98 \text { to } 1.35\end{array}$ & $\begin{array}{l}1.16 \\
0.99 \text { to } 1.36\end{array}$ & $\begin{array}{l}1.40 \\
1.17 \text { to } 1.68\end{array}$ & $\begin{array}{l}0.96 \\
0.81 \text { to } 1.12\end{array}$ & $\begin{array}{l}1.19 \\
1.00 \text { to } 1.43\end{array}$ & $\begin{array}{l}1.26 \\
0.99 \text { to } 1.61\end{array}$ \\
\hline
\end{tabular}

Those relative risks that differ significantly from the reference category at $95 \%$ confidence level are in bold type.

In addition, we found a significant interaction between the level of urbanisation and father's occupation. Socioeconomic differences in pregnancy risk increased with the level of urbanisation of the place of residence and were particularly large in the capital city area (fig 1). It seems that the high level of teenage pregnancy in the capital applies first and foremost to girls from blue collar families.

\section{DISCUSSION}

The main findings of our study can be summarised as follows:

- There were large differences in teenage pregnancy risk by socioeconomic status (measured by father's occupation and the level of education), particularly in the capital city area (Helsinki).

- Swedish speaking girls had a lower pregnancy risk than their Finnish speaking counterparts, and this also remained so when their different distributions by socioeconomic status were taken into account.

- Differences in teenage pregnancy risk by family structure were large. Girls from intact two parent families had the lowest pregnancy risk and early home leavers the highest. The higher pregnancy risk of girls who live with an own parent and a step-parent compared with girls who lived in a one parent family was a new finding.

- There was no systematic change in most sociodemographic differentials in the teenage pregnancy risk from 1987 to 1998, and the changes in the sociodemographic structure did not explain the levelling off of the downward trend in pregnancy risk. However, there was some increase over time in the differences by family structure.
- The differences in the socioeconomic characteristics of the regions did not explain regional differentials in teenage pregnancy risk. The differences by level of urbanisation were to a large extent explained by the variation of family structure by urbanisation.

\section{Assessment of data}

Our results are based on a large nationally representative dataset that was set up to analyse the occurrence of pregnancies by various background characteristics over a period of time. The response rates of the baseline surveys ranged from $84 \%$ to $88 \%$, which allows us to be confident in generalising the results for the entire teenage population of Finland over the study period. We were able to measure the pregnancy rate of the non-respondents, because their data were also linked to registered pregnancies. The teenage pregnancy rate of the non-respondents was $71 \%$ higher than that of the respondents, which is consistent with some earlier findings where the non-respondents have been found more likely to be engaged in health compromising behaviours than the respondents. ${ }^{36}$ Given the difference in the pregnancy rate between the respondents and the non-respondents, it is also likely that there are more girls from lower socioeconomic background among the non-respondents. Even if the pattern of sociodemographic differences among the non-respondents was different, it would have only a negligible effect on the results, given their low proportion.

It is important from the point of view of the reliability of our results that the information on the outcome variable was not self reported and came from high quality registers. This allows us to rule out the under-reporting of undesirable life events (abortions and miscarriages) as a known source of bias. The 


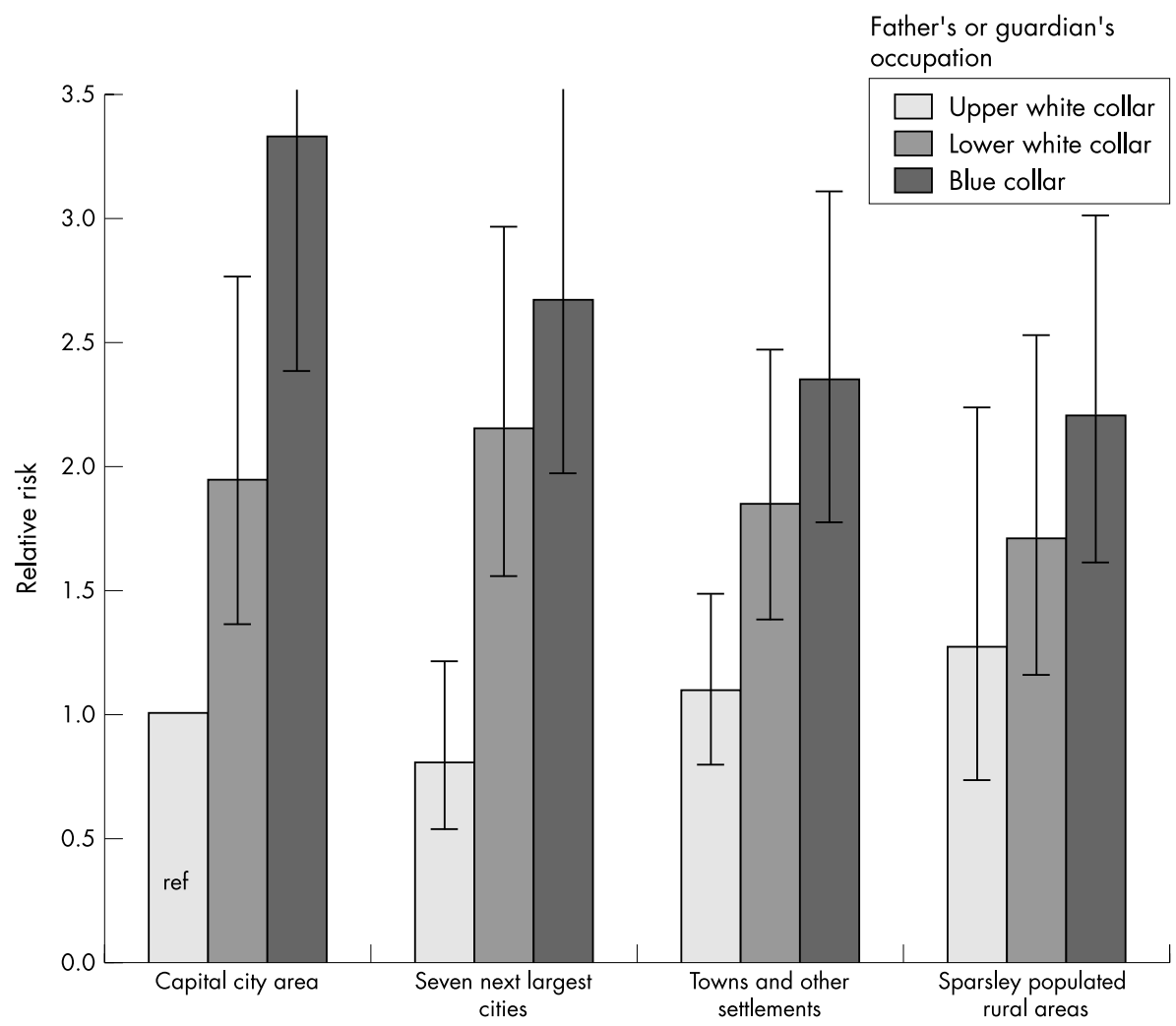

Figure 1 Relative teenage pregnancy risks by level of urbanisation and father's or guardian's occupation.

Level of urbanisation

dataset also included most pregnancies that ended in miscarriage. Altogether this enabled us to provide better estimates for the sociodemographic differentials than has been possible in most previous studies on teenage pregnancies.

\section{Sociodemographic differences}

\section{Socioeconomic status}

Macintyre and West ${ }^{37}$ have studied how the different indicators of socioeconomic status are related to its association with health in adolescence. They concluded that the patterns observed in the different dimensions of health were remarkably consistent between the different occupational measures, and many non-occupational measures (housing, income, and car availability) did not consistently produce differences not already detected by the occupational measures. Hence, it is likely that there would not be any essential change to our results if more refined measures of socioeconomic status could be applied.

Based on research from other countries we expected the finding that adolescents from lower socioeconomic background had a higher pregnancy risk. Although there were large differences by both indicators of socioeconomic background in our study, they appear modest in comparison with the social class differences in teenage birth rates in England and Wales, where the difference between the opposite ends of the social class distribution was almost 10 -fold. ${ }^{14}$ Our results show somewhat smaller differences than those reported for the United States, where daughters of fathers from a manual occupation had 3.6 times the odds of having a pre-marital birth by the age of $23,{ }^{11}$ and where the odds of giving birth at teenage were reduced in the range of $6 \%$ to $11 \%$ by each year of the mother's education, depending on the study and reference population..$^{10}{ }^{17}$ In these comparisons it has to be borne in mind that the Finnish teenage pregnancy rate is on a level less than a quarter of that in the United States, and about one third of that in England and Wales. In Switzerland, where the level is close to that of Finland, Narring et al ${ }^{12}$ found no differences by socioeconomic status of the father. Their result may, though, partially result from the study design, because they included only 15-20 year olds enrolled at post-mandatory schools.

The crucial importance of adolescence is that during this phase of life health differences are created that are likely to remain in adulthood. ${ }^{38}{ }^{39}$ Several studies have shown that the experience of a teenage pregnancy, and particularly a teenage birth, is a predictor of social and health disadvantages in later adult life. ${ }^{40} 41$ Teenage pregnancy can thus be viewed both as a cause and consequence of social exclusion ${ }^{42}$ and as one of the channels that transmits socioeconomic differences across generations.

\section{Family structure}

As expected, girls who live in a nuclear family with both parents were clearly distinguished as the category with the lowest pregnancy risk. This is consistent with previous findings from other countries. ${ }^{10} 16214344$

Our results show that those who move into a partnership in adolescence have the same very high pregnancy risk as the girls who do not live together with parents or with a partner. This suggests that those who start a partnership early do not use contraception adequately and that they, to a certain extent, share the risk behaviours of all the adolescents who do not live with parents. However, among those who reported living with a partner there may also be a proportion of intended pregnancies that contributes to their high pregnancy risk. It has been found in other research that adolescents who do not live with parents not only have a high pregnancy risk, ${ }^{12}{ }^{15}$ but also display by far the most health problems and health compromising behaviours ${ }^{45}$ and they have the highest mortality. ${ }^{46}$ They have also been found to have problems later in their educational and family careers. ${ }^{47-49}$ Our findings suggest that early home leavers are a risk group in terms of early pregnancies. 


\section{Key points}

- Considerable sociodemographic differences in the occurrence of teenage pregnancies exist also in a welfare society like Finland.

- No systematic change in socioeconomic differentials was found in teenage pregnancy risk from 1987 to 1998

- Girls living with an own parent and a step-parent had a higher pregnancy risk than girls living in a one parent family.

- Given the impressive decline in teenage pregnancies in Finland until the mid-1990s, the absolute sociodemographic differences have diminished.

Girls in stepfamilies and one parent families showed levels of pregnancy risk placed at an intermediate level between those living with both parents and those in a partnership or not living together with the parents. However, it was somewhat surprising to find that girls from stepfamilies had a higher pregnancy risk than those from one parent families. To our knowledge, this has not been previously reported, and earlier research provides different results on the effect of stepfamilies on the adolescent in comparison with one parent families. There is evidence that the wellbeing of adolescents in stepfamilies is at an intermediate level between those from one parent families and those in intact families, and is closer to the level of intact families..$^{50}$ Teenage girls from one parent families have also been found to report more emotional problems than girls from stepfamilies. ${ }^{51}$ On the other hand, it has been shown that young men and women in stepfamilies are more likely than those in one parent families to leave home because of friction ${ }^{52}$ and they also leave home earlier than the adolescents from intact and one parent families. ${ }^{53}$ Our results support the idea that the entry of a step-parent into the family may cause problems for children, and could result in involvement with risk behaviours (E Bernhardt et al, PAA annual meeting, Washington, DC, March 2001).

In our analyses it was shown that the sex of the parent with whom the adolescent stayed after the break up of the parental family did not have any effect on pregnancy risk. In fact, the girls living with only the father had levels of pregnancy risk remarkably close to those living with only the mother, and girls living with father and stepmother had an equal risk to those who lived with mother and stepfather. As a shortcoming in this respect, we do not have information on when the last transition in the parental family occurred, nor on the changes in the parental family during the follow up. To gain a deeper insight into the reasons for the different pregnancy risks between girls from these two types of families, family relations would have to be considered in addition to family composition, as it has been argued that the adolescent's good relationship with at least one adult in the family may be a better predictor of the adolescent's behaviour than the family structure itself. ${ }^{50}$

\section{Mother tongue}

Our finding of the lower teenage pregnancy rate in the Swedish speaking population is in accordance with earlier research on the more favourable health situation in this minority group. Hyyppä and Mäki ${ }^{27}$ have hypothesised that the level of social cohesion or social capital can explain the health differences between the two language groups, especially as they could not be attributed to socioeconomic characteristics. It may well be the case that factors related to social behaviour can also explain the differences in teenage pregnancy risk between the two population groups. There are reasons to believe that the social behaviour of the Swedish speaking minority differs from that of the Finnish speaking majority ${ }^{54}$ and the Swedish speaking community has a higher level of social cohesion because of its small size, strong institutional network, cultural activity, and geographical stability. Minority language can also be regarded as an indicator of social cohesion, and the considerably lower divorce rate among the Swedish speaking population may be understood as another indicator of social integrity. ${ }^{55}$

\section{Change over time}

During the study period there was some change in the distribution of adolescents by occupation and level of education of their parents, and by family structure. The rise in completed levels of education over time is reflected in the increasing proportion of adolescents whose father had 12 or more years of education (from $12 \%$ in 1987 to $23 \%$ in 1997) or was an upper white collar employee (from 16\% in 1987 to $24 \%$ in 1997). There has also been some effect of the increasing divorce rate on the family structure of adolescents: the proportion of adolescents who did not live with both parents increased from $21 \%$ in 1987 to $25 \%$ in 1997. Neither the change in socioeconomic background nor that in the family structure influenced the temporal change in the teenage pregnancy rate. Relative differences in teenage pregnancies by family structure somewhat increased over time, but there was no systematic change over time in socioeconomic differences and in the differences by mother tongue and region. The large and persistent differences by socioeconomic status tell us that the Finnish policies that aim at reducing socioeconomic health differences have not been particularly successful with respect to teenage pregnancies.

\section{Regional differences}

The known regional differences in the Finnish teenage pregnancy rate ${ }^{3856}$ were confirmed in our data, but the known regional differences in socioeconomic structure and urbanisation did not explain the regional differences in the teenage pregnancy rate. One possible reason for the fact that the regional variation in teenage pregnancies was not reduced in our study, when we took socioeconomic variables into account, may be that we did not have specific measurements of regional context. For a deeper understanding of the influence of socioregional context on the teenage pregnancy rate, regional level information on the various aspects of social context has to be obtained and analysed by multilevel models.

Teenage pregnancy and abortion rates in the capitals of all the Nordic countries are higher than those in other parts of the country. ${ }^{57}$ In our data, the difference between the capital city and other larger towns in Finland appeared rather small, while there were differences between them and the less urbanised areas. Moreover, we were able to explain the differences in pregnancy risks between areas of different urbanisation level by the family structure. The proportion of adolescents who lived with both parents decreased by urbanisation $(87 \%$ in sparsely populated rural areas and $69 \%$ in the capital city area, other categories in between), and that was sufficient to explain the differences. At the same time, socioeconomic status played an opposite part. The more urban areas, and especially the capital city area, had a larger proportion of adolescents from upper white collar backgrounds $(41 \%$ in the capital city area, $7 \%$ in sparsely populated rural areas, others in between) whose pregnancy risk in general was lower, and it appeared that the socioeconomic differences were more pronounced in the capital city than in the rest of the country.

In this study, the place of residence was measured at the time of the survey and the possible subsequent moves could not be covered. It is known that there has been an ongoing migration from the more rural areas and from the northern and eastern part of Finland to the urban centres in the south, to the capital in particular. ${ }^{58} 59$ This holds also for older teenagers, many of whom move to study. If the urban context of the 
capital enhances behaviours that increase the teenage pregnancy rate, that would also influence the pregnancy rate of those who come to the capital at teenage. In that case, the actual difference between the capital and other regions may be even larger than we measured, because those who moved to Helsinki at teenage are recorded as living at their place of departure in our data.

\section{Sexual behaviour}

It has been estimated in several studies that adolescents from lower socioeconomic groups engage in sexual activities earlier. ${ }^{60}{ }^{61}$ This has been confirmed in Finland. ${ }^{62}$ In accordance with this, Kosunen et al ${ }^{63}$ have found that girls from lower socioeconomic groups in Finland are more likely to be oral contraceptive users already at the age of 16. It has also been shown that adolescents who live in intact nuclear families with their parents start sexual relations considerably later than those who have experienced the break up of their parents' union (MR Moore, 2000 Meeting of the American Sociological Association, Washington, DC, 2000). ${ }^{446465}$ Even if adolescents from the less favourable background were to know about contraception and apply contraception with the same success as adolescents from more affluent and stable family backgrounds, the differences in exposure would result in differences in pregnancy rates. It is thus likely that at least in part, the sociodemographic differences in adolescent pregnancy rates are explained by sexual behaviour, namely by the earlier start of sexual relations by adolescents from lower socioeconomic groups or incomplete families.

Sexual behaviour among Finnish adolescents has been monitored by repeated surveys since the mid-1980s. Between 1986 and 1997 the results of these studies did not suggest any remarkable change in adolescent sexual activity ${ }^{66}$ However, the latest results from the School Health Promotion Study suggest that proportions of adolescents who had experienced their first sexual intercourse by the end of comprehensive school (mean age 15.8 years) increased from 29\% to 32\% among girls and from $24 \%$ to $27 \%$ among boys in the late $1990 \mathrm{~s}{ }^{67}$ This is likely to be related to the levelling off of the teenage pregnancy trend in the second half of the 1990s.

\section{Concluding remarks}

Our study showed that also in a welfare society like Finland there are considerable sociodemographic differences in the occurrence of teenage pregnancies. These differences have persisted over time, although the level of the teenage pregnancy rate has decreased. Legislation and population and family policies in Finland have aimed at reducing socioeconomic and regional differences, ${ }^{68}$ and these targets have not yet been achieved with respect to relative differences in teenage pregnancies. However, given the impressive decline in teenage pregnancies that continued until the mid-1990s in all sociodemographic groups, the absolute sociodemographic differences in teenage pregnancies have diminished and are at an essentially lower level than in Britain or the United States.

\section{ACKNOWLEDGEMENTS}

The authors wish to thank the National Research and Development Centre for Welfare and Health (STAKES) and Statistics Finland (permission TK-53-1619-99) for granting access to their data sets, and Anja Rasimus and Jouni Meriläinen for their help in the work with the register data at STAKES.

\section{Authors' affiliations}

A Vikat, Max Planck Institute for Demographic Research, Rostock, Germany

A Rimpelä, University of Tampere, School of Public Health, Finland E Kosunen, University of Tampere, Medical School, Finland

M Rimpelä, National Research and Development Centre for Welfare and Health (STAKES), Finland
Funding: the first stages of the study and the process of building up the joint register data set were financed by a grant from the Finnish Ministry of Social Affairs and Health (RASKE Project) and the Academy of Finland (Research Programme on Health and Other Welfare Differences between Population Groups, and a post-doctoral fellowship for Andres Vikat). The Adolescent Health and Lifestyle Survey was supported by the Ministry of Social Affairs and Health.

Conflicts of interest: none.

\section{REFERENCES}

1 Rimpelä $M$, Rimpelä A, Kosunen E. From control policy to comprehensive family planning: success stories from Finland. Promot Educ 1996;3:28-32.

2 Gissler M, Ulander VM, Hemminki E, et al. Declining induced abortion rate in Finland: data quality of the Finnish Abortion Register. Int J Epidemiol 1996;25:376-80.

3 Kosunen E, Rimpelä $M$. Towards regional equality in family planning: Teenage pregnancies and abortions in Finland from 1976 to 1993. Acta Obstet Gynecol Scand 1996;75:540-7.

4 STAKES. Births, abortions, sterilisations and congenital anomalies 1999-data supplier feedback 14/2000. Helsinki: STAKES, 2000.

5 Statistics Finland. Vital statistics 1999. Population 2000:13. Helsinki: Statistics Finland, 2000

6 Bankole A, Singh S, Haas T. Characteristics of women who obtain induced abortion: A worldwide review. International Family Planning Perspectives 1999;25:68-77.

7 Council of Europe. Recent demographic developments in Europe 2000. Strasbourg: Council of Europe, 2000.

8 Henshaw SK. Unintended pregnancy in the United States. Fam Plann Perspect 1998;30:24-9.

9 Rasch V, Knudsen L, Wielandt H. Pregnancy planning and acceptance among Danish pregnant women. Acta Obstet Gynecol Scand 2001;80: 1030-5.

10 Kahn JR, Anderson KE. Intergenerational patterns of teenage fertility. Demography 1992;29:39-57.

11 Cherlin AJ, Kiernan KE, Chase-Lansdale PL. Parental divorce in childhood and demographic outcomes in young adulthood. Demography 1995;32:299-318

12 Narring F, Michaud PA, Sharma V. Demographic and behavioral factors associated with adolescent pregnancy in Switzerland. Fam Plann Perspect 1996;28:232-6.

13 Manlove J. Early motherhood in an intergenerational perspective-the experiences of a British cohort. Journal of Marriage and the Family 1997:59:263-79.

14 Botting B, Rosato M, Wood R. Teenage mothers and the health of their children. Population trends: a publication of the Goverment Statistical Service 93. London: Office for National Statistics, 1998: 19-28.

15 Moore KA, Manlove J, Glei DA, et al. Nonmarital school-age motherhood: family, individual, and school characteristics. Journal of Adolescent Research 1998;13:433-57.

16 Hockaday C, Crase SJ, Shelley MC, et al. A prospective study of adolescent pregnancy. J Adolesc 2000;23:423-38.

17 Manlove J, Terry E, Gitelson L, et al. Explaining demographic trends in teenage fertility, 1980 -1995. Fam Plann Perspect 2000:32:166-75.

18 Smith T. Influence of socioeconomic factors on attaining targets for reducing teenage pregnancies. BN 1993;306:1232-5.

19 Gould JB, Herrchen B, Pham T, et al. Small-area analysis: targeting high-risk areas for adolescent pregnancy prevention programs. Fam Plann Perspect 1998:30:173-6.

20 Nebot M, Borrell C, Villalbí JR. Adolescent motherhood and socioeconomic factors. European Journal of Public Health 1997;7: 144-8.

21 Manlove J, Mariner C, Papillo AR. Subsequent fertility among teen mothers: longitudinal analyses of recent national data. Journal of Marriage and the Family 2000;62:430-48.

22 Rigsby DC, Macones GA, Driscoll DA. Risk factors for rapid repeat pregnancy among adolescent mothers: a review of the literature. Pediatr Adolesc Gynecol 1998:11:115-26.

23 Karvonen S, Rimpelä A. Socio-regional context as a determinant of adolescents' health behaviour in Finland. Soc Sci Med 1996;43: 1467-74

24 Karvonen S, Rimpelä A. Diminishing regional contrasts? The East-West-divide in health behaviour among Finnish adolescents. Health \& Place 1998:4:161-70.

25 Valkonen T. Psychosocial stress and sociodemographic differentials in mortality from ischaemic heart disease in Finland. Acta Medica Scandinavica 1982; (suppl 660):152-64.

26 Koskinen S. Origin of regional differences in mortality from ischaemic heart disease in Finland. STAKES Research Reports 41 . Helsinki: STAKES, 1994

27 Hyyppä MT, Mäki J. Why do Swedish-speaking Finns have longer active life? An area for social capital research. Health Promotion International 2000; 16:55-64.

28 Kosunen E, Vikat A, Gissler $M$, et al. Teenage pregnancies and abortions in Finland in the 1990s. Scand J Public Health (in press)

29 Notkola IL. Abortions and previous births. In: OFS (Official Statistics of Finland), Health 1993:3. Induced abortions in Finland until 1991. Helsinki: National Research and Development Centre for Welfare and Health, 71-87. 
30 Fu $\mathbf{H}$, Darroch JE, Henshaw SK, et al. Measuring the extent of abortion underreporting in the 1995 National Survey of Family Growth. Fam Plann Perspect 1998;30:128-33, 138

31 Teperi J. Multimethod approach to the assessment of data quality in the Finnish medical birth registry. J Epidemiol Community Health 1993:47:242-7.

32 Gissler $M$, Teperi J, Hemminki E, et al. Data quality after restructuring a national medical registry. Scand J Soc Med 1995;23:75-80.

33 Gissler M, Louhiala P, Hemminki E. Nordic medical birth registers in epidemiological research. Eur J Epidemiol 1997;13:169-75.

34 Hemminki E. Treatment of miscarriage: current practice and rationale. Obstet Gynecol 1998;91:247-53.

35 Aitkin M, Anderson D, Francis B, et al. Statistical Modelling in GLIM. Oxford Statistical Science Series. Oxford: Oxford University Press, 1989.

36 Rimpelä A, Rimpelä M, Vikat A, et al. Nuorten terveystapatutkimus: Tupakointi ja päihteet 1977-1997. [Adolescent Health and Lifestyle Survey: smoking, alcohol and drugs 1977-1997]. Themes from Finland 28/1997. Helsinki: STAKES, 1997:73

37 Macintyre S, West P. Lack of class variation in health in adolescence: an artefact of an occupational measure of social class? Soc Sci Med 1991;42:395-402

38 Wadsworth MEJ. Health inequalities in the life course perspective. Soc Sci Med 1997;44:859-69.

39 Koivusilta L, Rimpelä A, Rimpelä $M$, et al. Health behaviour-based selection into educational tracks starts in early adolescence. Health Education Research: Theory \& Practice 2001;16:201-14.

40 Hobcraft J, Kiernan K. Childhood poverty, early motherhood and adult social exclusion. CASE Paper 28. London: Centre for Analysis of Social Exclusion, 1999

41 Hoffman SD. Teenage childbearing is not so bad after all .... Or is it? A review of the literature. Fam Plann Perspect 1998;30:236-9, 243.

42 Social Exclusion Unit. Teenage pregnancy. London: Social Exclusion Unit, 1999

43 McLanahan S, Bumpass L. Intergenerational consequences of family disruption. American Journal of Sociology 1988:94:130-52.

44 Kiernan KE, Hobcraft J. Parental divorce during childhood: age at first intercourse, partnership and parenthood. Population Studies 1997;51:41-55

45 Rimpelä A, Karvonen S, Rimpelä $M$, et al. Nuorten terveystottumusten väestöryhmittäiset erot ja elinolot 1977-87: Toteutuiko terveyspoliittinen jakaumatavoite? [Socio-economic and regional differences in health habits of young people in Finland in 1977-87:The attainment of Health for All by the Year 2000 target "Equal distribution of health".] Lääkintöhallituksen julkaisuja: Terveyden edistäminen. Sarja Tutkimukset 1/1990. Helsinki: Valtion painatuskeskus, 1990.

46 Valkonen T, Martelin T, Rimpelä A, et al. Socio-economic mortality differences in Finland 1981-90. Population 1993:1. Helsinki: Statistics Finland, 1993

47 Goldscheider FK, Goldscheider C. Leaving home before marriage: ethnicity, familism, and generational relationships. Madison, WI: University of Wisconsin Press, 1993

48 Goldscheider FK, Goldscheider C. The effects of childhood family structure on leaving and returning home. Journal of Marriage and the Family 1998:60:745-56.

49 White L, Lacy N. The effects of age at home leaving and pathways from home on educational attainment. Journal of Marriage and the Family 1997;59:982-95.
50 Spruijt E, de Goede $M$. Transitions in family structure and adolescent well-being. Adolescence 1997;32:897-911.

51 Garnefski N, Diekstra RFW. Adolescents from one parent, stepparent and intact families: Emotional problems and suicide attempts. J Adolesc 1997;20:201-8.

52 Kiernan KE. The impact of family disruption in childhood on transitions made in young adult life. Population Studies 1992;46:213-34.

53 Goldscheider FK, Goldscheider C. The changing transition to adulthood. Leaving and returning home. Thousand Oaks, CA: SAGE Publications, 1999.

54 Liebkind K. Minority identity and identification processes: A social psychological study. Helsinki: Commentationes Scientiarum Socialium No 22, 1984.

55 Finnäs F. Social integration, heterogeneity, and divorce: The case of the Swedish-speaking population in Finland. Acta Sociologica 1997;40:263-77

56 Vikat A, Kosunen E, Rimpelä M. Induced abortions in Finland 1987-1988. Statistical Report 39/1999. Helsinki: STAKES, 1999.

57 Gissler M, ed. Induced abortions in the Nordic countries. Statistical Report 10/1999. Helsinki: STAKES, 1999.

58 Korkiasaari J, Söderling I. Muuttoliike [Migration]. In: Koskinen S, et al, eds. Suomen väestö [Population of Finland]. Helsinki: Gaudeamus, 1994:226-64.

59 Sullström R, Laakso S, Loikkanen H. Finnish population centres growing UNITAS 1997:69:9-15.

60 Goodson P, Evans A, Edmundson E. Female adolescents and onset of sexual intercourse: a theory-based review of research from 1984 to 1994. J Adolesc Health 1997;21:147-56.

61 Manning WD, Longmore MA, Giordano PC. The relationship context of contraceptive use at first intercourse. Fam Plann Perspect 2000;32:104-10

62 Kontula O. Cultural terms of sexual initiation. Helsinki: VAPK-kustannus, 1991. [In Finnish with English summary].

63 Kosunen E, Rimpelä A, Rimpelä M. Sixteen-year-old oral contraceptive users in Finland, 1981-1993. Scand J Soc Med 1995;23:236-41.

64 Flewelling RL, Bauman KE. Family structure as a predictor of initial substance use and sexual intercourse in early adolescence. Journal of Marriage and the Family 1990;52:171-81.

65 Whitbeck LB, Yoder KA, Hoyt DR, et al. Early adolescent sexual activity: a developmental study. Journal of Marriage and the Family 2000:61:934-46.

66 Kosunen E, Rimpelä M, Liinamo A et al. Nuorten seksuaalikäyttäyłyminen Suomessa 1996-1997 [Adolescent sexual behaviour in Finland 1996-1997]. Suomen Lääkärilehti 1998:53:3353-60

67 Kosunen E, Rimpelä M, Liinamo A, et al. Suomalaisten nuorten seksuaalikäyttäytymisen muutokset 1990-luvun lopulla [Trends in adolescent sexual behaviour in Finland in the late 1990s. In Finnish, abstract in English]. Sosiaalilääketieteellinen Aikakauslehti [Journal of Social Medicine] 2000;37:273-82.

68 Ministry of Social Affairs and Health. Terveyttä kaikille vuoteen 2000: Uudistettu yhteistyöohjelma. [Health for All 2000: Revised Co-operation Programme.] Sosiaali- ja terveysministeriön julkaisuja [Publications of the Ministry of Social Affairs and Health]. 1993:2. Helsinki: Valtion Painatuskeskus, 1993 